\title{
Development of Diabetes Education on Online-based Application: Telemondia
}

\author{
Atyanti Isworo', Yogi Ramadhani ${ }^{2}$, Akhyarul Anam ${ }^{3}$, Wahyu Ekowati ${ }^{4}$, Ariesta Salwa Azalia ${ }^{5}$ \\ ${ }^{1}$ Department of Nursing, Faculty of Health Sciences, Jenderal Soedirman University \\ ${ }^{2}$ Department of Electrical Engineering, Faculty of Engineering, Jenderal Soedirman University \\ ${ }^{3}$ Department of Nursing, Faculty of Health Sciences, Jenderal Soedirman University \\ ${ }^{4}$ Department of Nursing, Faculty of Health Sciences, Jenderal Soedirman University \\ ${ }^{5}$ Student of Informatics Engineering, Faculty of Engineering, Jenderal Soedirman University
}

\section{ARTICLE INFO}

Article history:

DOI:

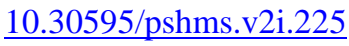

Submitted:

December 6, 2021

Accepted:

January 21,2022

Published:

January 26, 2022

Keywords:

Application;

Education; Online

\begin{abstract}
During the Covid 19 pandemic, a safe, efficient and effective educational method for diabetes patients is needed. Currently, an online-based education has developed, but this education is one-way, so the monitoring process is not getting enough attention. For this reason, it is necessary to develop online-based education in two directions so that there is interaction between patients, families and health workers. The purpose of this study is to develop a two-way online application-based education. The research method is research and development design. In the first phase, an online-based education development will be carried out with stages of design activities, validation and application acceptance testing. The results showed that an online application-based educational prototype named Telemondia had been composed and was validated by two diabetes education experts and two IT (Information Technology) experts. The following results from expert validation show the average aspect of ease of use of application is $90 \%$; content clarity is $96.87 \%$; aesthetic is $84.75 \%$; instructional quality is 87.5 ; and feedback quality is $85.42 \%$, with an average overall aspects of $87.87 \%$. This shows that Telemondia is very feasible to use. Furthermore, in the acceptance test for 25 diabetic patients, the results of this acceptance test show ease of use of application is $92 \%$; content clarity is $93 \%$; aesthetic is $84 \%$; instructional quality is 87 ; and feedback quality is $86 \%$. The average overall aspect is $88.11 \%$, which means that Telemondia can be accepted by patients. Further development will be made to add features that allow recording audio and video.
\end{abstract}

This work is licensed under a Creative Commons Attribution 4.0 International License.

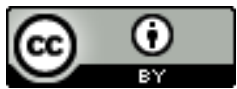

Corresponding Author:

Atyanti Isworo,

Department of Nursing, Faculty of Health Science, Jenderal Soedirman University

Banyumas, Indonesia

Email: atyanti.isworo@gmail.com

\section{INTRODUCTION}

Diabetes is a chronic disease caused by metabolic disorders in the body in controlling the balance of sugar levels. The number of diabetes patients is always increasing every year, even in 2017 the number of diabetes patients in the world reached 425 million. Diabetes cases in Indonesia have a prevalence of $6.2 \%$ of the total adult population, so that Indonesia has the largest diabetes case in Southeast Asia. [11]

Diabetes is a challenging disease. This is because diabetes management requires obedience for the patients. Health care providers know that only patients who adhere to treatment recommendations will be able to achieve good glycemic control and avoid complications related to diabetes. In fact, many patients are unable to perform the recommended treatment and become frustrated.

This frustration can be manifested in the form of disobedience. Diabetic patients in implementing their health care often experience non-compliance. The non-adherent to dietary recommendations is $75.9 \%$, 
non-adherent to self-monitoring blood glucose $(83.5 \%)$; as many as $4.3 \%$ are not adherent to the prescribed drugs, $23-52 \%$ of poor foot care, and non-adherent to physical exercise ranged from $70-81 \%$. [3]

One of the efforts to address diabetes self-care non-compliance is education. Diabetes education has become an important component of diabetes management and an integral part of chronic disease management. The aim of the education for diabetic patients is to optimize metabolic control, prevent both acute and chronic complications, improve quality of life by influencing knowledge, attitudes and behavior to be healthy. [1]

Several studies have shown that education has a positive impact on diabetes management and care costs. Such as research conducted by Healy, Black, Hariis, Lorenz \& Dungan, 2013; Duncan, et al., 2011 and Robbins, Thatcher, Webb \& Valdmanis, 2008 stated that education decreases the length of treatment so that the cost of care is lower. Education increases HbA1c levels. [20]

Education also has a positive effect on other clinical symptoms, psychosocial aspects and behavioral aspects of diabetes care. Education can also reduce the development of diabetes complications [21], improve the quality of life and lifestyle behaviors such as a healthy diet and regular physical activity [4], increase self-efficacy and healthy coping [22], and reduce distress due to diabetes and depression. [6]

Education has indeed been proven to be able to improve patient lifestyle behaviors. However, since the Covid-19 pandemic, activities for treating and examining diabetes patients in health facilities have been limited, due to fairly strict health protocols. This becomes one of the obstacles for the care and monitoring of diabetes patients, because so far it is more face-to-face treatment between health workers and patients. This is of course quite difficult for patients, families, and health workers. Patients find it difficult to consult, families also find it difficult to get direct information from health workers, as well as health workers who find it difficult to monitor the patient's condition.

To overcome the limitations/obstacles mentioned above, it can be done by developing a communication application that can connect patients with health workers, online. Previous studies have shown that online-based diabetes education is able to increase knowledge of diabetes, dietary pattern, and physical activity of patients. Diabetes applications that have been developed in previous studies use sms services and web based education. [2]

However, in previous studies, the communication process in the application used tended to be oneway, using brochures to compile material on web pages, and there was no monitoring process for diabetic patients. Most of the existing applications use English with an interface that is quite difficult for diabetes patients to understand in Indonesia.

Furthermore, in this study, an application that is specific for communication between diabetes patients and health workers was developed, especially in Indonesia, can be accessed using a mobile device that is quite widely used in the society, and has ease of use. The system developed in this study is called TeleMonDia (Tele Monitoring Diabetes). This system is a software that can be installed on Android-based devices, and can also be accessed using a web browser on a computer.

The TeleMonDia system is designed to communicate in two directions between health workers and patients or families, with a data communication model in the form of visual data (text). This system will later be used for education and counselling between patients and health workers. This two-way communication is used to monitor the development of diabetes patients. The communication process between patients/families and health workers will provide good diabetes education. [19]

Thus, the results of developing this system in the future are expected to improve the diabetes education process, and also improve compliance with diabetes patients.

\section{RESEARCH METHOD}

In this study, TeleMonDia's prototype design was made, using the internet and an Android-based device. This system's prototype was made using several equipment with the following specifications:

1. Server : using PHP language

2. Application on the Android devices: using Java language

3. Webserver on metroworldhost.com.

4. The program used : Bootstrap Studio, XAMPP, Apache Cordova 8, MySQL 5, and Android Simulator, running on Windows 10 64-bit Operation System

5. The android device used requires a minimum of Android 5.

Application / software development in this study uses the waterfall method, starting from the requirements analysis stage to implementation. The waterfall method is one of the methods commonly used in software engineering, and has a fairly easy flow in its implementation. [15] 
The Telemondia application development flowchart is as follows.

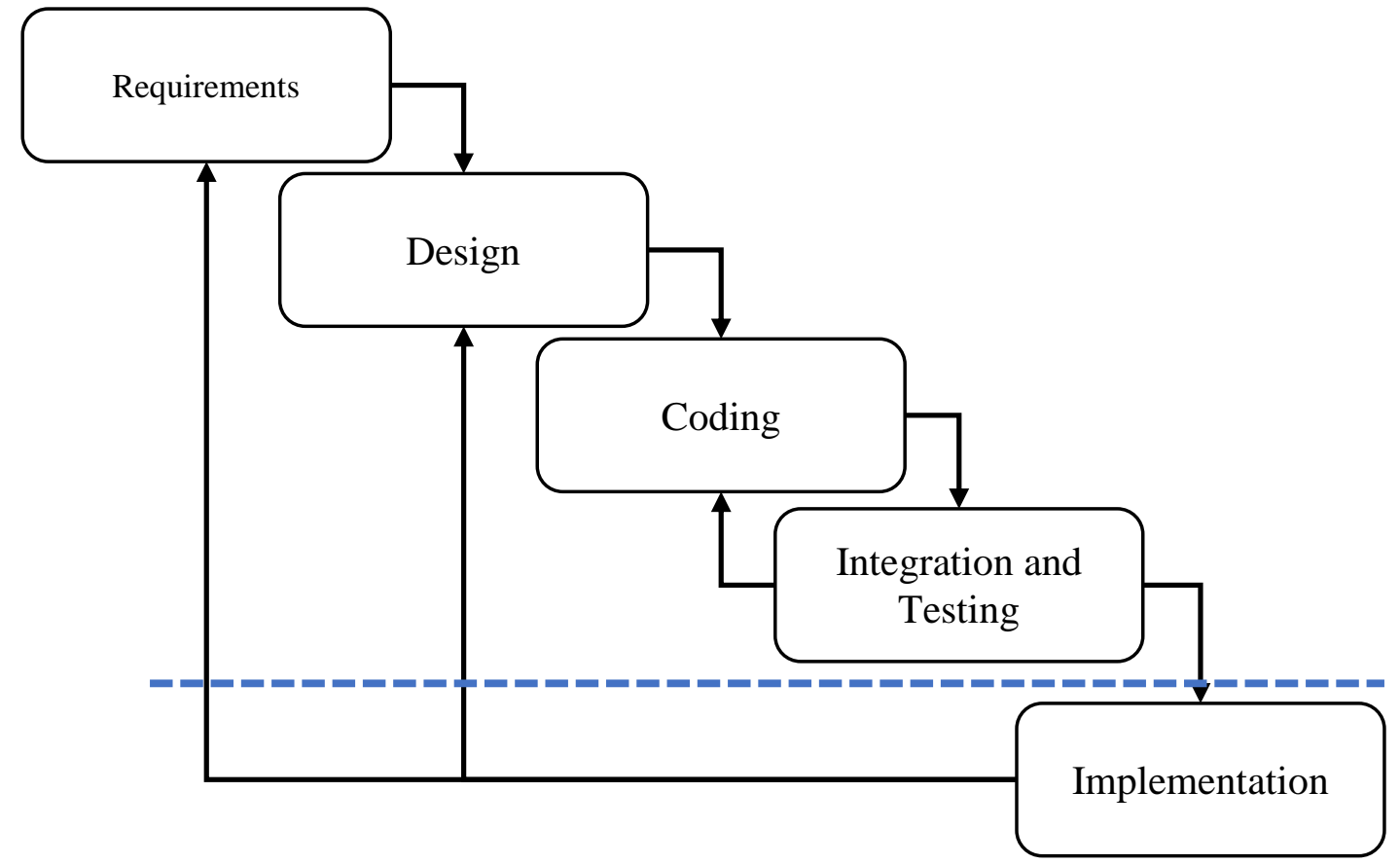

Figure 1. Telemondia Development Flow

\section{A. Requirements}

The first step in developing Telemondia in this study is to analyse the system requirements. In this step, the requirements that need to be handled by the system is identified, as follows:

a. Can do a 2-way consultation between patient/family and health workers.

b. Using devices with low system requirements, and not requiring access to large data communications.

C. Easy-to-understand interface design.

\section{B. Design}

From the results of the requirements, the system design is created, which is described in UML (Unified Modeling Language) modeling (ISO, IEC 19505-12012), in the form of use-case diagrams and data flow diagrams as shown in Figure 2 and Figure 3 below.

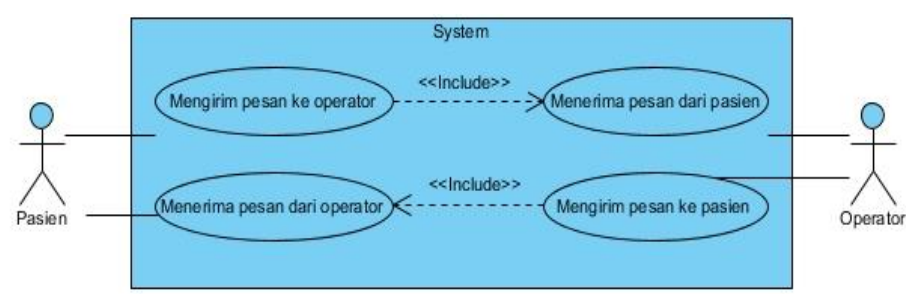

Figure 2. Use Case Diagram Telemondia 


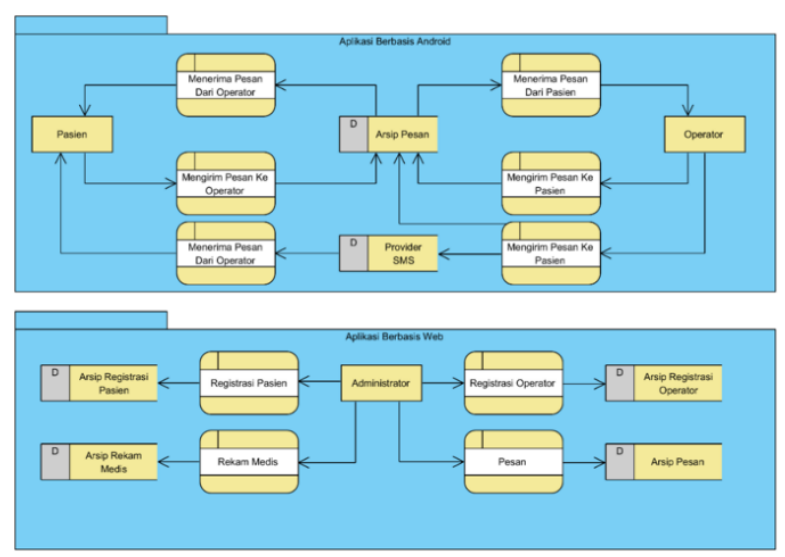

Figure 3. Data Flow Diagram Telemondia

In Figure 2 and 3, the communication process between patients and health workers is shown through the Telemondia application. The data flow from the patient to the server and then forwarded to the operator/health worker. The process of sending the data can be through the interface in the Telemondia application or via SMS. This system is also designed to be able to store various communication data and patient medical data. [14] For data storage needs, using a MySQL basis, with an entity relationship diagram in Figure 4 below.

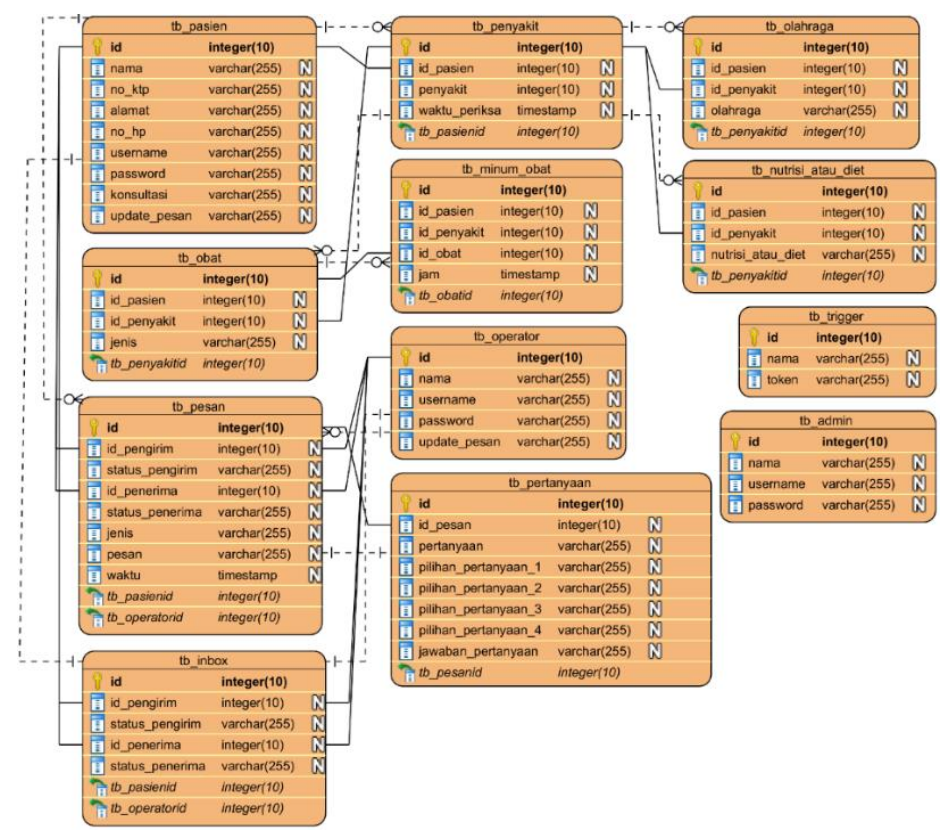

Figure 4. Entity Relationship Diagram Telemondia

\section{Coding}

The system design is translated in the form of coding to be compiled into a program. The coding process is carried out using the PHP language for the website interface, and using Java for the application interface on Android. Figure 5 shows an example of the coding process written using Visual Studio Code. 


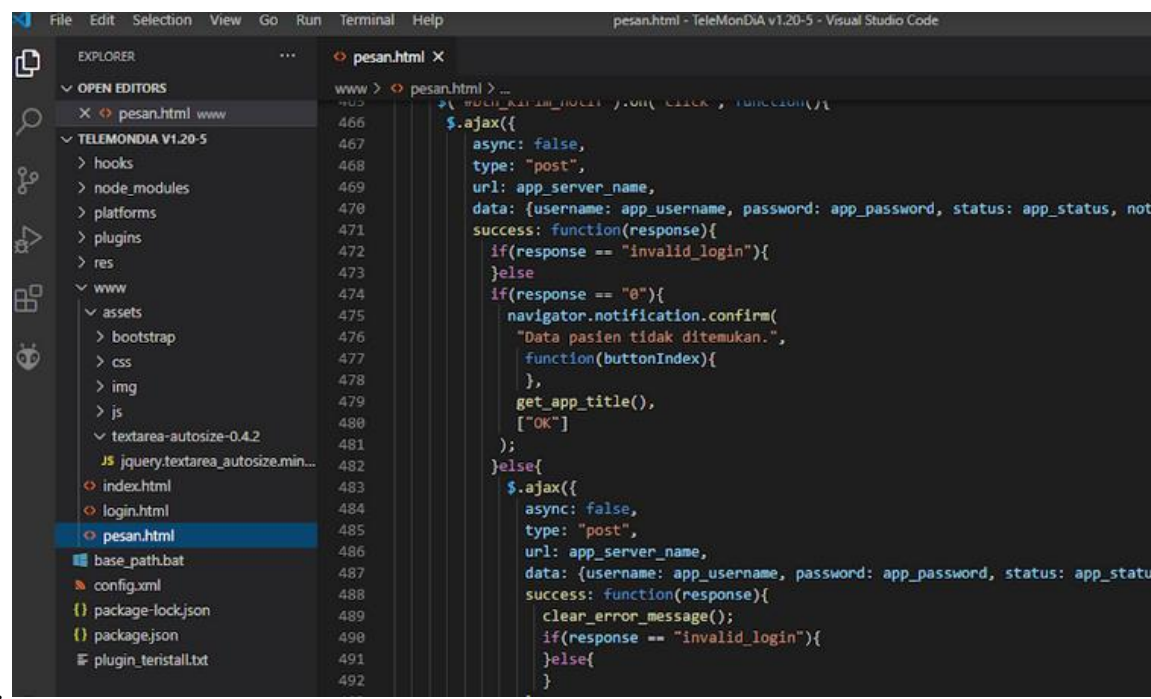

Figure 5. Telemondia Source Code Snippets

\section{Testing}

System testing is carried out in several stages. Initial testing, performed during the compilation of the source code, is used to see some possible bugs. In this initial test there were relatively no problems, and the Telemondia application, both the mobile version and the web version, ran well.

The next test is the expert validation. In this test, involving experts in the field of diabetes education and in the field of technology. An expert in DM education is two nurse who has about more than 10 years of experience in diabetes education, while an expert in technology is two IT expert who has worked for 10 years in IT development.

Furthermore, the acceptance test for Telemondia was performed. The Telemondia system prototype was tested on 25 patients with diabetes. The results of this test are further described in the Results and Discussion chapter.

\section{RESULT AND DISCUSSION}

\section{A. Result of Telemondia Application Prototype Design}

The results showed that an online-based diabetes education application called Telemondia has been compiled. This application can be used on a smartphone or using web. The advantage of this application is that it can send messages in real time from patients to health workers or vice versa. This application uses a webserver addressed at www.telemondia.id, which is connected to an android device that has Telemondia installed. The Telemondia application interface on Android devices and on computers can be seen in Figure 6 (a) and 4 (b).

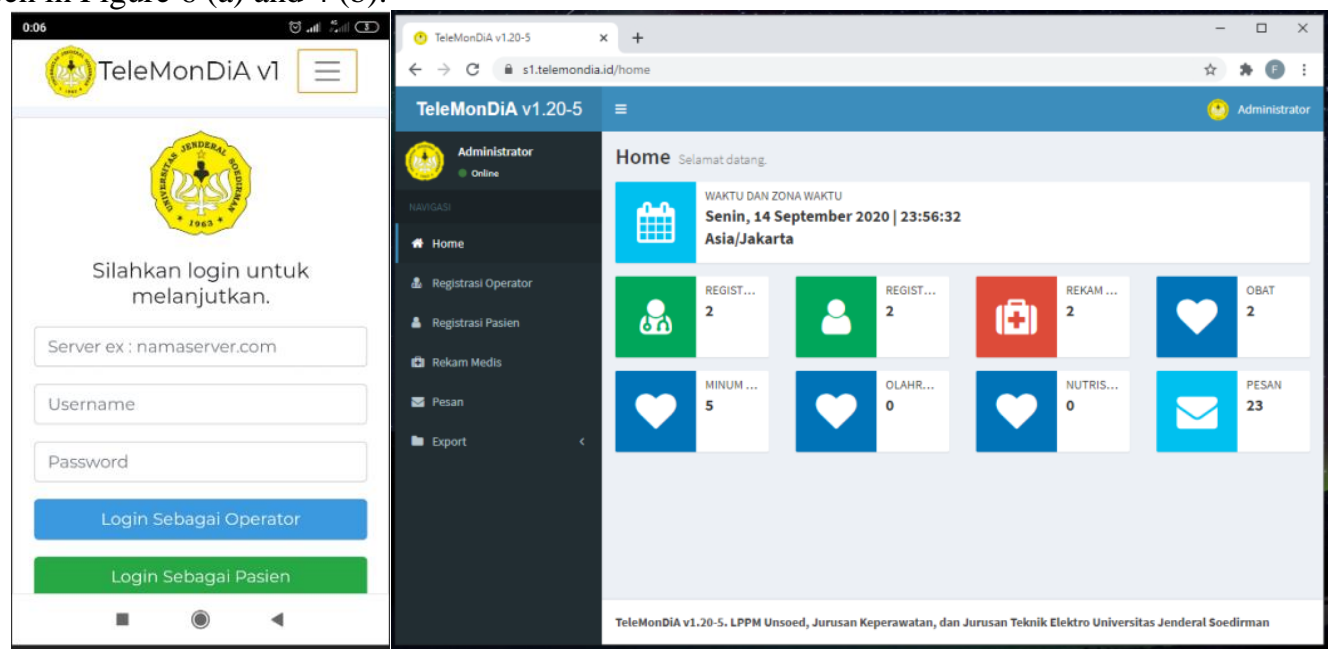

(a)

(b)

Figure 6. Interface on (a) android device, and (b) computer web browser 
In Telemondia system, there are different types of accounts between patients and health workers. The two accounts differ in terms of access rights regarding data on the web server. Health workers can connect with many patients, and can edit medical data on patient accounts such as medical history, illnesses, and drugs that must be taken. Patient accounts can receive reminder messages from the system, and from the healthcare workers, such as reminders when to take medication. Patient accounts can only be accessed through an application installed on an Android device. Figure 7 shows a simple interface design, which is easy for the patient to understand and use.

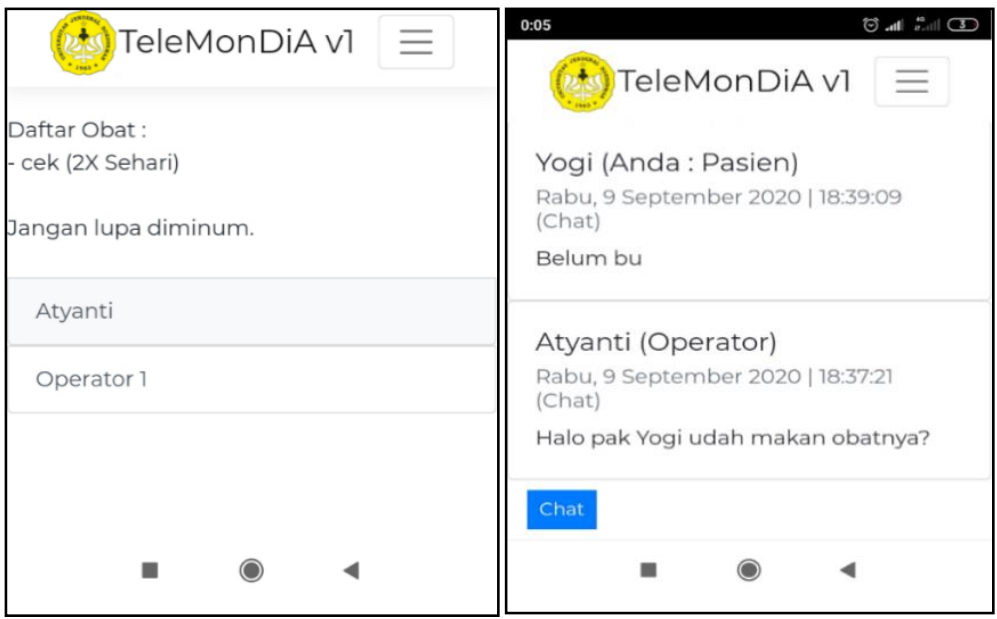

Figure 7. Telemondia application run on Android device

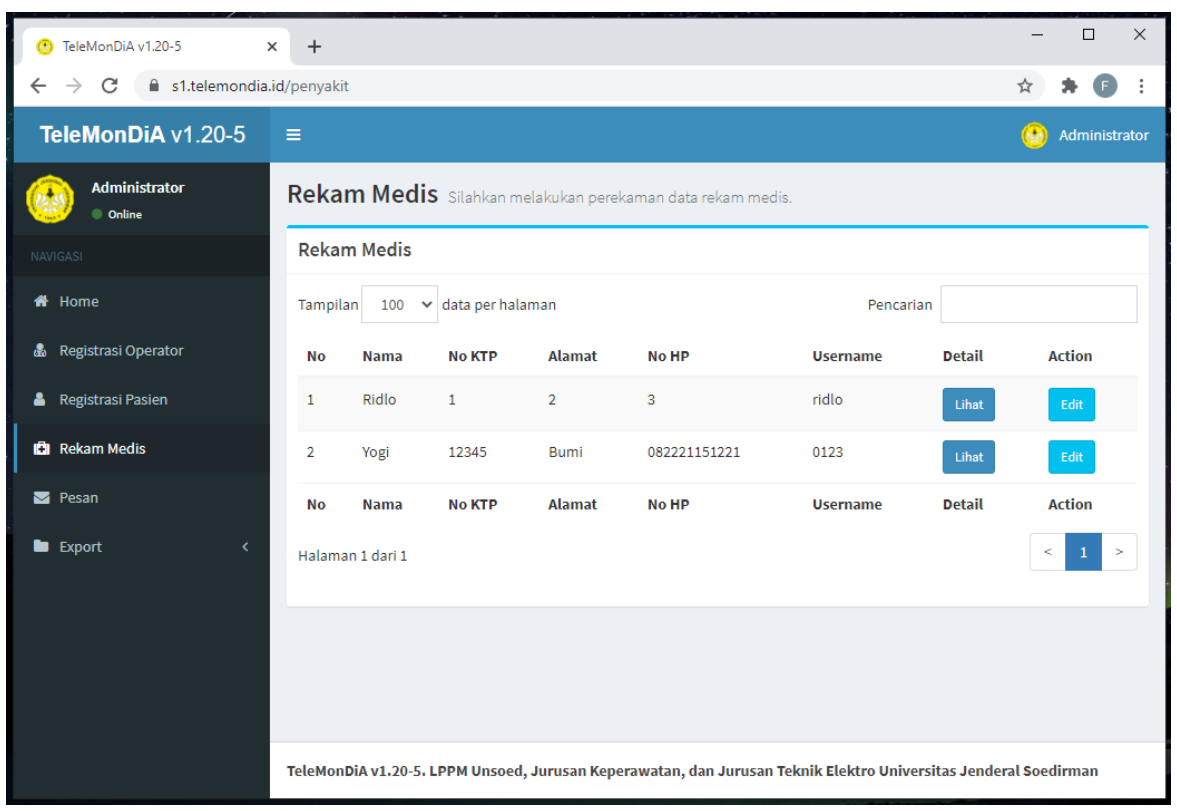

Figure 8. Access Medical Record Data on the telemondia.id Page

Figure 8 shows a sample display of access to patient medical record data by health workers via a web browser on a computer, with a simple and easy-to-use interface. Access is done via telemondia.id page, with servers located in the country, so that the access time is very fast. However, to access the Telemondia application on Android devices, it is still not available on the Playstore. To install the application on an Android device, users need to open the http://telemondia.id page then download the installation file (.apk) from that page.

From the results of application testing, to access the telemondia.id page, both logging in as a health worker and for the installation file download process, there are no obstacles. Even so, the Telemondia version 1 application is designed to run on the Android 4.4 system and above, so that users who are still using Android 4.2 cannot use Telemondia. 


\section{B. Experts Validation}

The prototype design developed was assessed by the validator using an evaluation sheet adopted from Kusumadewi's research (2016). Expert validation is carried out by diabetes education experts and Information technology experts. Diabetes education experts are two nurses who work at Margono Soekarjo Hospital and have worked as nurses for more than 20 years and more than 10 years in the field of diabetes education. They are also certified as diabetes educators from the Indonesian Diabetes Educators Association. Meanwhile, IT experts are two lecturers at Jenderal Soedirman University who are involved in application development. They have been working for almost 12 years. The prototype design developed is assessed by the validator using a validation sheet.

The following is a validation sheet developed by the researcher covering aspects of application use, material clarity, aesthetics, instructional quality and feedback quality. Each aspect has an indicator that is rated from a range of $1-4,1=$ very inappropriate, $2=$ inappropriate, $3=$ appropriate, $4=$ very appropriate. The table below contains each aspect along with its indicators and assessment criteria

\begin{tabular}{|c|c|c|c|}
\hline No & Aspect & Indicator & Assessment Criteria \\
\hline 1. & \multirow[t]{5}{*}{ Ease of Use } & \multirow[t]{2}{*}{ Ease of use of media } & How to use this application is simple \\
\hline 2. & & & I can quickly understand how to use this application \\
\hline 3. & & \multirow[t]{2}{*}{$\begin{array}{l}\text { Navigation } \\
\text { accuracy }\end{array}$} & $\begin{array}{l}\text { The buttons in the application are in accordance with } \\
\text { the intended page }\end{array}$ \\
\hline 4. & & & $\begin{array}{l}\text { The layout of the navigation buttons is clear and not } \\
\text { confusing }\end{array}$ \\
\hline 5. & & Media operations & This application can run smoothly when used \\
\hline 6. & \multirow[t]{2}{*}{ Material clarity } & Use of language & The language used is easy for me to understand \\
\hline 7. & & Materials presented & The material presented is easy to learn \\
\hline 8. & \multirow[t]{5}{*}{ Aesthetic } & \multirow{2}{*}{$\begin{array}{l}\text { The attractiveness of the } \\
\text { interface }\end{array}$} & I like the look of this app \\
\hline 9. & & & $\begin{array}{l}\text { The interface of this application is good and } \\
\text { attractive }\end{array}$ \\
\hline 10. & & Neatness & Neat layout of menus, text, images and other content \\
\hline 11. & & \multirow[t]{2}{*}{ Graphical display interface } & $\begin{array}{l}\text { The use of colors, backgrounds and images is not } \\
\text { boring }\end{array}$ \\
\hline 12. & & & The text presented is clear and easy to read \\
\hline 13. & \multirow[t]{2}{*}{$\begin{array}{l}\text { Instructional } \\
\text { quality }\end{array}$} & \multirow[t]{2}{*}{ Application provides help } & $\begin{array}{l}\text { This app makes it easy for me to learn about diabetes } \\
\text { self-care }\end{array}$ \\
\hline 14 & & & This app helps me in studying diabetes treatment \\
\hline 15. & \multirow[t]{3}{*}{ Feedback quality } & \multirow[t]{3}{*}{ Feedback } & $\begin{array}{l}\text { This application has a question and answer feature } \\
\text { (feedback) }\end{array}$ \\
\hline 16. & & & The feedback given is according to my needs \\
\hline 17. & & & $\begin{array}{l}\text { This application makes it easy for me to ask health } \\
\text { workers }\end{array}$ \\
\hline
\end{tabular}

Analysis of validator's answers used descriptive statistics (Putro, 2012) in the range of scores as follows:

Table 1

Category

Very valid

value

Valid

4

$82-100$

Invalid

3

percentage

Very invalid

1

2

63-81

$44-62$

The percentage of validator assessment is calculated using the following formula:

$P P V=\frac{\sum \text { Validator'sanswer }}{\sum \text { Maximumscore }} \chi 100 \%$

Description:

$\mathrm{PPV}=$ Percentage of validator assessment

$\Sigma$ Validator's answer $=$ number of validator's answer

$\Sigma$ Maximum score $=$ total maximum score of the indicator 
The results of the telemondia prototype validation from the first validator was $88.23 \%$, the second validator was $89.70 \%$ and the third validator was $86.76 \%$ and the fourth validator was $86.76 \%$. The average value of the validation results of the four validators is 87.87 (very valid). Based on the validator's assessment, each aspect that was assessed was declared valid, with the results of the ease of use of the application, material clarity, aesthetics, instructional quality and feedback quality respectively $90 \% ; 96.87 \% ; 84.75 \%$; $87.5 \%$; and $85.42 \%$.

\begin{tabular}{|c|c|c|c|c|c|c|c|c|}
\hline Aspect & $\begin{array}{l}\text { Validator } \\
\text { Score }\end{array}$ & 1 & $\begin{array}{l}\text { Validator } 2 \\
\text { Score }\end{array}$ & $\begin{array}{l}\text { Validator } 3 \\
\text { Score }\end{array}$ & $\begin{array}{l}\text { Validator } 4 \\
\text { Score }\end{array}$ & $\begin{array}{l}\text { Validator's } \\
\text { Average } \\
\text { Score }\end{array}$ & $\begin{array}{l}\text { Max } \\
\text { Score }\end{array}$ & $\begin{array}{l}\text { Eligibility } \\
\text { Percentage }\end{array}$ \\
\hline Ease of Use & 18 & & 19 & 18 & 17 & 18 & 20 & 90 \\
\hline Material Clarity & 8 & & 8 & 7 & 8 & 7.75 & 8 & 96.87 \\
\hline Aesthetic & 17 & & 17 & 17 & 16 & 16.75 & 20 & 84.75 \\
\hline $\begin{array}{l}\text { Instructional } \\
\text { Quality }\end{array}$ & 7 & & 7 & 7 & 7 & 7 & 8 & 87.5 \\
\hline Feedback Quality & 10 & & 10 & 10 & 11 & 10.25 & 12 & 85.42 \\
\hline $\begin{array}{l}\text { Average } \\
\text { Eligibility } \\
\text { Percentage }\end{array}$ & 88.23 & & 89.70 & 86.76 & 86.76 & 59.75 & 68 & 87.87 \\
\hline
\end{tabular}

\section{Design Revision}

After getting an assessment and input from the expert validator, the researcher revised the application according to the validator's input so that the resulting product is appropriate and feasible to use. The validators suggest improvements to the appearance and color, so we improved this design according to suggestions from expert validators.

\section{Model Acceptance Test (Usage Test)}

At this stage, the application was installed on the Android smartphone of diabetic patients at the Puskesmas in Purwokerto. The trial was done by 25 diabetic patients. During the trial, patients were given an instrument to respond to Telemondia's design.

The table below describes patient acceptance of Telemondia.

\begin{tabular}{|l|l|l|l|}
\hline Aspect & $\begin{array}{l}\text { Average respondent's } \\
\text { answer }\end{array}$ & $\begin{array}{l}\text { Maximum } \\
\text { Score }\end{array}$ & Eligibility Percentage \\
\hline Ease of Use & 18.4 & 20 & $\mathbf{9 2}$ \\
\hline Material clarity & 7.44 & 8 & $\mathbf{9 3}$ \\
\hline Aesthetic & 16.8 & 20 & $\mathbf{8 4}$ \\
\hline Instructional quality & 6.96 & 8 & $\mathbf{8 7}$ \\
\hline Feedback quality Eligibility & 10.32 & 12 & $\mathbf{8 6}$ \\
\hline $\begin{array}{l}\text { Average } \\
\text { Percentage }\end{array}$ & 68.92 & $\mathbf{8 8 . 1 1}$ \\
\hline
\end{tabular}

The table above illustrates that the telemondia was well received by patients $(88.11 \%)$. The ease- of use aspect of the application get an average percentage of $92 \%$, material clarity 93\%, Aesthetics $84 \%$, instructional quality and feedback quality $86 \%$ each.

\section{CONCLUSION}

Telemondia's development to monitor DM patient compliance has been carried out and the application is running well. Data communication between patients and health workers is going well, supported by a simple and easy-to-understand interface.

Further research is expected to improve the features of Telemondia by adding audio and video communication features. In addition, testing is needed on a wider scope, so that the accuracy of the level of effectiveness of the application can be obtained in improving the compliance behavior of DM patients. 


\section{Acknowledgements}

The team of authors expresses great gratitude to the Ministry of Education and Culture of the Republic of Indonesia and the Institute for Research and Service at Jenderal Soedirman University for their support in this research, particularly financial support through research grants.

\section{REFERENCES}

[1] Atak, N., Gurkan, T., \& Kose, K., "The effect of education on knowledge, self management behavior and self efficacy of patients with type 2 diabetes," Australian Journal of Advanced Nursing; 6, 2009.

[2] Avdal EU, Kizilci S, Demirel N., "The effects of web-based diabetes education on diabetes care results: a randomized control study," Computer Informatics Nursing ; 29 (2 Suppl): Tc29-Tc34, 2011.

[3] Bonger, Z., Shiferaw, S., Tariku, E.Z., "Adherence to diabetic self-care practices and its associated factors among patients with type 2 diabetes in Addis Ababa," Ethiopia. Patient Prefer Adherence; 6: 963-970, 2018

[4] Cooke D, Bond R, Lawton J., "U.K. NIHR DAFNE Study Group. Structured type 1 diabetes education delivered within routine care: impact on glycemic control and diabetes-specific quality of life," Diabetes Care ;36:270-272, 2013.

[5] Duncan, I., Ahmed, T., Li QE., Stetson, B., Burton, K., Rosenthal, D., Fitzner, K. Assessing the value of the diabetes educator. Diabetes Educator 2011; 37:638-657.

[6] Fisher L, Hessler D, Glasgow RE., " REDEEM: a pragmatic trial to reduce diabetes distress," Diabetes Care ;36:2551-2558, 2013.

[7] Glasgow RE, Kurz D, King D., "Internet-based diabetes self management support program," Patient Education Counseling, 87: 81-92, 2012.

[8] Healy, S.J., Black, D., Hariis, C., Lorenz, A., Dungan, K.M., "Inpatient diabetes education is associated with less frequent hospital readmission among patients with poor glycemic control," Diabetes Care;36: 2960-2967, 2013.

[9] Heinrich E, de Nooijer J, Schaper NC. "Evaluation of the web-based Diabetes Interactive Education Programme (DIEP) for patients with type 2 diabetes," Patient Education and Counselling ;86:172-178, 2012.

[10] Hermanns N, Schmitt A, Gahr A, Herder, C., Nowotny, B., Roden, M., Ohmann, C., Kruse, J...Kulzer, B., "The effect of a diabetes-specific cognitive behavioral treatment program (DIAMOS) for patients with diabetes and subclinical depression: results of a randomized controlled trial," Diabetes Care; 38 (4), 2015.

[11] International Diabetes Federation (IDF), IDF Diabetes atlas. 8th edition. International Diabetes Federation, 2017. www.diabetesatlas,org

[12] ISO/IEC 19505-1, Information technology - Object Management Group Unified Modeling Language (OMG UML) - Part 1: Infrastructure", 2012.www.iso.org. Diakses pada 10 Desember 2020.

[13] Kusumadewi, W.A.P," Pengembangan media pemebelajaran berbasis android pada mata pelajaran pemograman dasar kelas X di SMK Negeri 3 Surabaya". Jurnal IT-Education, 01 (01), 2016.

[14] Norris SL, Lau J, Smith SJ, Schmid CH, Engelgau MM., "Self-management education for adults with type 2 diabetes: a meta-analysis of the effect on glycemic control", Diabetes Care ;25:1159-1171, 2002.

[15] Pressman, R.S., "Software Engineering: A Practitioner's Approach," New York: McGraw-Hill, 2018.

[16] Putro, W.E., "Teknik Penyusun Instrumen Penelitian", Yogyakarta: Pustaka Pelajar, 2012.

[17] Robbins JM, Thatcher GE, Webb DA, Valdmanis VG. 2008. Nutritionist visits, diabetes classes, and hospitalization rates and charges: the Urban Diabetes Study. Diabetes Care ;31:655-660

[18] Setiyani, L., "Rekayasa perangkat lunak [Software Engineering]" Karawang: Jatayu Catra Internusa, 2019.

[19] Sowah, A.A. Bampoe-Addo, "Design and Development of Diabetes Management System Using Machine Learning," International Journal of Telemedicine and Applications; (5):1-17, 2019.

[20] Steinsbekk A, Rygg LO, Lisulo M, Rise MB, Fretheim A., "Group based diabetes self- management education compared to routine treatment for people with type 2 diabetes mellitus. A systematic review with meta-analysis," BMC Health Service of Research;12:213, 2012.

[21] Stratton IM, Adler AI, Neil HA., "Association of glycaemia with macrovascular and microvascular complications of type 2 diabetes (UKPDS 35): prospective observational study," $B M J ; 321: 405-412$, . 
2000.

[22] Thorpe CT, Fahey LE, Johnson H, Deshpande M, Thorpe JM, Fisher EB. "Facilitating healthy coping in patients with diabetes: a systematic review," Diabetes Education;39:33-52, 2013.

[23] Trento M, Passera P, Borgo E., "A 5-year randomized controlled study of learning, problem solving ability, and quality of life modifications in people with type 2 diabetes managed by group care," Diabetes Care;27:670-675, 2004 